Sklar's own contribution leans to recommending a "developmental democracy" of a kind that could be emerging in Zimbabwe, or even in Zambia, but the possible model of Niger's "development society" produces immediate reservations. He also does not even begin to discuss the whole idea of Peoples' Defence Committees in Ghana, which although some may fail because of the association with far-fetched Gaddafian ideas of representation as the "negation of democracy," can also trace antecedents in traditional African ideas which relate more to "direct" democracy. It may have its faults, may even prove unworkable, but then, "liberal democracy" as it was practised on two occasions in Ghana was hardly a success. The problem, above all, is to create institutions which correspond to what Sklar calls "the renowned African tradition of community-wide participation in decision-making." And so the experiments will continue.

\title{
LETTERS
}

\section{Questing the Ouija}

Dear Dr. Cosentino:

I am writing to you in regard to the fact that Barnes \& Noble, a division of Harper \& Row, has commissioned me to write a nonfiction book about the ouija board-its history and a discussion of ouija board theory and phenomena.

Thus, my question is: Will you, Dr. Cosentino, put forward for me to the members of the Association a call for information and material about this subject matter for inclusion in the book?

Because the book is to be both serious and objective, I can assure you that all material will be quoted with strict accuracy and properly placed within the intended conceptual context of each correspondent.

For that reason, if material (views, interpretations, evaluations, studies, etc.) is forwarded, it would be good if the correspondent also included his or her biography or resume to assure correct referencing in regard to degrees held, titles and/or areas of discipline.

Specifically, I am looking for answers to this question: Is there in the African heritage a fore-runner of the ouija board or planchette? Was such an early instrument a part of African civilization?

Early fore-runners can be found in the cultures of ancient China, Greece and North America. If such also existed (or yet exists) as a part of the African experience, some further questions are: What was the name of the instrument? What did it look like? What was it made of? And what were its uses: Communication with spirits and divinities? The locating of lost articles, even lost persons? Ceremonial determinations - what to do, how to do it, and when?

I can be reached directly by mail or telephone. If correspondence is initiated, I will be pleased to telephone interested individuals to conduct in-depth interviews via longdistance, if numbers are provided.

In the meanwhile, I wish to thank you even now for your time and cooperation in putting forward of my request for information, Dr. Cosentino. I look eagerly forward to your response, and am

Sincerely yours,

Andrew Piotrowski 


\section{SEARCHING FOR CORRESPONDENTS:}

I, along with a friend, have organized an "Afrikan History and Culture Class" here in Lewisburg Penitentiary. We are just getting started and we would like to make as many contacts as possible in order to get assistance in terms of Afrikan literature, news, history, etc. If there's anything you can do for us to help us teach Afrikan history and culture to prisoners, please contact me. If not, we still recognize your contribution to the Afrikan liberation struggle. Sincerely,

Maurice Francois \#87550-132

USP Lewisburg, Pa 17837

\section{RETRACTION AND APOLOGY}

Dear Professor Mazrui,

Please accept my most sincere apologies for the regrettable damage which you have suffered as a result of my December 1975 Dar es Salaam Conference paper, which was subsequently reprinted in a book entitled "Dirty Work 2: The CIA in Africa" in the USA and England, edited by Louis Wolf et al.

I am writing to express my sincere regret that it contained references to yourself or statements which have been construed as referring to yourself, implying that you are or have been associated with the Central Intelligency Agency ("CIA") or have otherwise assisted or co-operated with the CIA or with any US Institution or governmental department, in attempting to penetrate and frustrate or endanger the liberation movements of Southern Africa. I wish expressly to withdraw unreservedly any statement or implication that you: have attempted to penetrate and suppress or endanger the liberation movements of Southern Africa; have engaged in research the purpose of which was to foster United States imperialism; have misrepresented the real purpose of your research in Africa; support the South African government's policy of apartheid; and are or have been counter-revolutionary or any enemy of freedom in Africa. There is, of course, no foundation whatsoever to support any such statement or implication. I know that you were and are at least as committed to justice and liberation in Southern Africa as I am. I must confess that in the stress of the period, my research was faulty and my conclusions therefore irresponsible.

Please accept my deepest apologies and my undertaking that I will not permit this paper to be republished in any form in the future which contains any reference to yourself or which may be construed in any way as referring to yourself.

I have agreed to pay your legal costs incurred in this matter, and I appreciate your agreeing not to press me for payment of any damages to which you would otherwise be entitled.

I do hope that your fear that this paper may adversely affect your professional academic and/or literary standing, whether in Africa or elsewhere, will prove to be unfounded.

Yours sincerely,

ROBERT MOLTENO

(See also ZED Press Apology in Special Announcements) 